\title{
Synopsis of a new taxonomic synthesis of Montiaceae (Portulacineae) based on rational metadata analysis, with critical new insights on historically poorly understood taxa and a reevaluation of historical biogeography
}

\author{
Mark Alan HERSHKOVITZ ${ }^{1}$ \\ ${ }^{1}$ Santiago, Chile \\ cistanthe@gmail.com
}

\begin{abstract}
Montiaceae (Portulacineae) comprise a clade of at least 270 species primarily of western America and Australia. This work uses existing phylogenetic metadata to elaborate a new cladistic taxonomic synthesis, and clarifies morphological circumscriptions of several poorly known species. A total of 21 taxa are validated, seven new and 14 necessary nomenclatural recombinations. Hypotheses of Montiaceae historical biogeography and phenotypic evolution are evaluated in light of recent metadata.
\end{abstract}

Key words: Montiaceae, taxonomy, phylogeny, biogeography, evolution, Calandrinia, Cistanthe, Lewisiopsis, Philippiamra, Rumicastrum

\section{Introduction}

This work presents a new cladistic taxonomy of Montiaceae (Portulacineae) and several of its included taxa, along with notes on the diagnostics of certainly poorly known species and new interpretations of phenotypic and biogeographic evolution. The present work includes 21 nomenclatural novelties. However, the whole of the novelty is greater than the sum of these parts. The generic circumscriptions and diversity estimates are modified from Hernández-Ledesma et al. (2015). The suprageneric taxonomy is the first proposed since McNeill (1974) and the only phylogenetic one. Critical reevaluation of certain common and usually misidentified Chilean taxa is the first since Reiche (1898). Existing metadata are interpreted as evidence for a hybrid origin of a genus. And existing metadata are interpreted as evidence for decoupling of cladogenesis with phenotypic evolution.

Montiaceae comprise a clade of at least 270 species plus about 20 accepted subspecific taxa, primarily of western America and Australia (Hernández-Ledesma et al., 2015; Ogburn and Edwards, 2015). Formerly, the family was included in the traditional but paraphyletic family Portulacaceae (Nyffeler and Eggli, 2010). Hershkovitz (1993) referred to a group he called Western American [including Australian] Portulacaceae. Molecular analysis (Hershkovitz and Zimmer, 1997) diagnosed a clade of Portulacaceae they called the PAW clade: Phemeranthus Raf., the Australian genus Rumicastrum Ulbrich, and geographically western American genera of Portulacaceae. Current Montiaceae were completed with the addition of Hectorellaceae (Applequist et al., 2006; Wagstaff and Hennion, 2006).

The modern cladistic generic classification originated with morphological analyses of Carolin (1987, 1993) and Hershkovitz (1991a, 1993). Slowly, the new familial and generic concepts began to replace the traditional concepts of Pax and Hoffman (1934) and McNeill (1974). Molecular evidence, beginning with Hershkovitz and Zimmer (1997), stimulated further acceptance of the cladistic classification and fomented several subsequent studies. Here I elaborate a modified cladistic supraspecific taxonomy based on molecular evidence, especially Hershkovitz (2006), Ogburn and Edwards (2015), and Hancock et al. (2018). 
The generic taxonomy supersedes that of Hernández-Ledesma et al. (2015), which superseded that of Carolin (1993). In addition, I comment on the taxonomy and taxonomic history of selected taxa, especially Calandrinia Kunth, Rumicastrum, and Cistanthe Spach and recombine binomials into Cistanthe, Calyptridium Nuttall and Philippiamra Kuntze. I conclude that Lewisiopsis has a hybrid origin and represents a living fossil. Finally, I offer detailed observations on taxonomically troublesome Chilean taxa. I initiate the work with a brief review of Montiaceae biogeographic history.

\section{Montiaceae biogeographic origins}

Montiaceae are sister to remaining Portulacineae, an order comprising several families that subsume the classical circumscription of Portulacaceae (Ogburn and Edwards, 2015). Montiaceae origins are not preserved in the fossil record. Current cladogram molecular clock-based estimates date the diversification of modern Montiaceae to between ca. 34 million (Ogburn \& Edwards, 2015) to ca. 43 million ybp, i.e., late Eocene to perhaps earliest Oligocene. These estimates are somewhat older but not terribly out of line with one based on ribosomal DNA mutation rates (Hershkovitz and Zimmer, 1997). At the same time, clock-based estimates indicate that diversification of modern species occurred from the Miocene onwards, much more recently than major lineage origins.

The age estimates corroborate Hershkovitz and Zimmer's $(1997,2000)$ view that the many intercontinental/interoceanic disjunctions among Montiaceae owe to long distance dispersal. The result is significant in that Montiaceae have no obvious morphological specialization to facilitate long distance dispersal via zoochory or anemochory. Carolin (1987) and earlier workers attempted to explain Portulacineae distributions in terms of vicariance resulting from the break-up of Gondwana.

Hancock et al. (2018) entertained a scenario whereby Rumicastrum could have arrived to Australia via Antarctica prior to the final separation of these continents, ca. 33 million years ago. They doubted this scenario, but it is all the more doubtful given the timing, geography, and ecological context of the necessary arrival/establishment of the Rumicastrum ancestor in Antarctica via South America. This connection was a narrow isthmus, in contrast to the continent-wide Australia-Antarctica connection. A shallow seaway is believed to have developed in the Drake Passage area at ca. 55 million years ybp, which is considerably older than the highest estimate of the Montiaceae crown divergence at ca. 43 million ybp. Short-distance dispersals might have been possible until the Miocene (Livermore et al., 2007), but the narrowness of the connection remains problematic. More importantly, by 30 million ybp, the oldest estimate for Rumicastrum divergence (Hancock et al., 2018), the warmer Eocene Antarctic climate had degenerated into a cold one (Francis et al., 2009). This renders unlikely migration across $5000 \mathrm{~km}$ of central Antarctica, and necessitates a 10,000 $\mathrm{km}$ peripheral route.

But the earliest-divergent Montiaceae, Phemerantheae and Cistantheae, like their nearest Portulacineae outgroups, are warmer and arid-adapted (Ogburn and Edwards, 2015). The range of Cistantheae centers in northernmost Patagonia, ca. $4000 \mathrm{~km}$ to the north of the Drake Passage. Eocene to Miocene climate of this region was warm (Hershkovitz et al., 2006). These data suggest the impossibility of overland migration of a warm- and arid-adapted proto-Rumicastrum 14,000 km to Australia via a cool/cold 
southern Patagonia/Antarctica in the timeframe of interest. Moreover, recalling other undisputable long distance dispersal events among Montiaceae (especially Hectorelleae), other Portulacineae, and angiosperms in general, a vicariance explanation for Rumicastrum is not inherently parsimonious.

A more trivial geographic aspect of Montiaceae origins relates to Chile. The first phylogenetic divergence separates Phemerantheae from the remainder of the family. The next divergence separates the largely Chilean Cistantheae from Montioideae, and the first split in the latter separates the largely Chilean Calandrinia. Thus, excluding Phemerantheae, the origin of rest of Montiaceae appears to have occurred in present day northern Chile. There, it diversified, many descendents dispersing to other lands and diversifying, dispersing, and diversifying further. This appears to be the only intercontinentally diverse plant lineage that originated in present day Chile. In fact Chile is known for its high phytogeographic endemism (Moreira-Muñoz, 2011), indicating that this region has been mainly a phytogeographic sink and not a source.

\section{Synopsis of subfamilial and generic taxonomy}

Below is a summary of a subfamilial to generic level taxonomy of Montiaceae, modified from Hernández-Ledesma et al. (2015) according to current phylogenetic evidence (see above). Each taxon comprises a clade. Numbers/letters in bold denote cladistic rank. Rank suffixes accord with conventional classification (McNeill et al., 2011) but no nomenclatural ranks are assigned per Cantino and De Queiroz (2007). Thus, missing ranks and conventional nomenclatural ranks can be assigned.

\section{Montiaceae Raf.}

\section{Montioideae}

1A. Montieae

\section{A1. Montiinae}

1A1a. Montia L.

1A1b. Claytonia L.

1A2. Lewisia Pursh

1A3. Lewisiopsis Govaerts

1B. Calandrinia Kunth

1C. Hectorelleae Appleq., Nepokr. \& W. L. Wagner

1C1. Hectorella Hook. f.

1C2. Lyallia Hook. f.

1D. Rumicastrum Ulbrich

2. Cistantheae Hershk.

2A. Cistanthe Spach

2B. Montiopsis Kuntze

2C. Calyptridinae Hershk.

2C1. Lenzia Phil.

2C2. Thingia Hershk.

2C3. Calyptridium Nutt. in Torr. \& A. Gray

2C4. Philippiamra Kuntze 
3. Phemerantheae Hershk.

3A. Phemeranthus Raf.

3B. Schreiteria Carolin

\section{Detailed and annotated subfamilial taxonomy}

The taxonomy below elaborates the synopsis above to the subgeneric level and includes estimated species numbers and distributions. Additional commentary is provided regarding phylogenetic evidence and taxonomic history. Conventional ranks are retained at the subgeneric level, because these have somewhat greater application in practice than suprageneric taxa. Monophyly of species is not presumed nor generally in evidence.

\section{Montiaceae Raf.}

\section{Montioideae}

\section{A. Montieae}

\section{A1. Montiinae}

1A1a. Montia L., Sp. P1. 1: 87. 1753; type: M. fontana L.

= Claytonia sect. Alsinastrum Torr. \& A. Gray, Fl. N. Amer. 1(2): 201. 1838.

= Claytonia sect. Naiocrene Torr. \& A. Gray, Fl. N. Amer. 1(2): 201. 1838.

= Claytonia subsect. Montiastrum A. Gray, Proc. Amer. Acad. Arts 22: 283. 1887.

= Crunocallis Rydb., Bull. Torrey Bot. Club 33: 139. $1906=$ Naiocrene (Torr. \& A. Gray)

Rydberg, Bull. Torrey Bot. Club 33: 139. 1906.

= Montiastrum (A. Gray) Rydberg, Fl. Rocky Mts. 265. 1917.

= Claytonia sect. Australiensis Poelln., Repert. Spec. Nov. Regni Veg. 30. 1932.

= Limnalsine Rydb., N. Amer. Fl. 21 (4): 25.1932.

= Mona Ö. Nillson, Bot. Not. 119: 266. 1966.

= Neopaxia Ö. Nilsson, Bot. Not. 119: 469. 1966.

= Maxia Ö. Nillson, Grana Palynol. 7: 359. 1967.

= Claytoniella Jurtzev, Bot. Zhurn. (Moscow \& Leningrad) 57: 644. 1972.

Ca. 18 species, eight in western North America to NE Asia, one species of northern South America, seven in New Zealand, one of Australia/New Zealand, and one cosmopolitan (O'Quinn, 2005; O'Quinn et al., 2005; Heenon, 2007; Miller and Chambers, 2007). How much of the range of the cosmopolitan Montia fontana L. is natural versus anthropogenic is not clear. Polymorphic, more than 30 heterotypic taxa are included in its synonymy (Tropicos.org, 2018). Within the past 50 years, Montia linearis (Dougl. ex Hook.) Greene has expanded to lower elevations adjacent to its past native range and has become adventive in the central and eastern US and in Europe (Hershkovitz, 1998a; Dembicz et al., 2015). 
1A1b. Claytonia L., Sp. Pl. 1: 204. 1753 EClaytonia [unranked] Euclaytonia Walp., Repert. Bot. Syst. 2: 237. 1843 ( nom. inval.) $\equiv$ Claytonia [unranked] Cormosae A. Gray, Proc. Amer. Acad. Arts 22: 278. 1887 EClaytonia sect. Cormosae A. Gray ex Poelln., Repert. Spec. Nov.; type: C. virginica L.

= Belia Steller ex S. G. Gmel., Fl. Sibir. 4: 88. 1769.

$=$ Limnia Haw., Syn. Pl. Succ.: 11. $1812 \equiv$ Claytonia sect. Limnia (Haw.) Torr. \& A. Gray, Fl. N. Amer. 1: 199. $1838 \equiv$ Montia sect. Limnia (Haw.) B. L. Rob., Syn. Fl. N. Amer. 1: 273. $1897 \equiv$ Claytonia subg. Limnia (Haw.) Holub, Preslia 47: 328. 1975.

$=$ Claytonia [unranked] Caudicosae A. Gray, Proc. Amer. Acad. Arts 22: 279. 1887.

$=$ Claytonia [unranked] Rhizomatosae A. Gray, Proc. Amer. Acad. Arts 22: 280. $1887 \equiv$

Montia [unranked] Rhizomatosae (A. Gray) B. L. Rob., Syn. Fl. N. Amer. 1: 272. $1897 \equiv$

Claytonia sect. Rhizomatosae (A. Gray) Poelln., Repert. Spec. Nov. Regni Veg. 30: 281, 296. 1932.

= Claytonia sect. Chenopodinae Poelln., Repert. Spec. Nov. Regni Veg. 30: 280. 1932.

Ca. 28 species with ca. 11 additional recognized subspecific taxa, mostly in western North America and NE Asia (O'Quinn, 2005; O'Quinn et al., 2005; Miller and Chambers, 2007). Claytonia sibirica and C. perfoliata are adventive in Europe, Australia, and New Zealand (Howell and Sawyer, 2006; Miller and Chambers, 2007; Atlas of Living Australia, 2018).

With a minor exception, subgeneric cladistic classification of Claytonia (O'Quinn, 2005; O'Quinn et al., 2005) corresponds approximately to the classical classification according to life form (annual, rhizomatous, tuberous, caudiciform), except that the last two form a single undifferentiated clade. None of the three principal life form clades is paraphyletic with respect to any other.

1A2. Lewisia Pursh, F1. Amer. Sept. 2: 360. 1813; type: L. rediviva Pursh. =Erocallis Rydberg, Bull. Torrey Bot. Club 33: 139. 1906.

= Oreobroma Howell, Erythea 1: 31. 1893.

Ca. 18 perennial species of western North America, plus five additional subspecific taxa, concentrated in California (Hershkovitz and Hogan, 2002; Wilson et al., 2005).

Limited molecular data (Hershkovitz, unpublished) suggest that the evergreen Lewisia sect. Cotyledon J. E. Hohn ex B. Mathew may be largely monophyletic, but there appears to be otherwise little phylogenetic structure in available data. The problematic, polymorphic, and widespread L. pygmaea (A. Gray) B. L. Rob. probably is polyphyletic, and interspecific gene flow involving several species may have taken place (Hershkovitz, unpublished). Most species have been intercrossed in cultivation, with varying degrees of hybrid fertility (Mathew, 1989; Davidson, 2000).

1A3. Lewisiopsis Govaerts, World Checkl. Seed Pl. 3(1): 21. $1999 \equiv$ Lewisia subg. Strophiolum J. E. Hohn ex B. Mathew, The Genus Lewisia 139. 1989 三 Cistanthe sect. 
Strophiolum (J. E. Hohn ex B. Mathew) Hershk., Phytologia 68: 268. 1990.; type: L. tweedyi (A. Gray) Govaerts $\equiv$ Lewisia tweedyi A. Gray.

One perennial species of central Washington State, USA, extending into southernmost British Columbia, Canada (Mathew, 1989; Davidson, 2000).

On morphological evidence, Hershkovitz (1990a, 1991a, 1992, 1993) transferred this taxon from Lewisia (Mathew, 1989; Davidson, 2000) to Cistanthe, later retreating from this position based on molecular evidence (Hershkovitz and Zimmer, 1997, 2000; Hershkovitz, 2006).

As I discuss in a work in preparation, on the basis of morphology and molecular data, Lewisiopsis appears to represent a "living fossil" consequent to hybridization between early divergent ancestors of Lewisia and Montiinae, followed by polyploidization and sequestering of further evolutionary change. This is evident in strongly conflicting relations based on nuclear and plastid DNA sequences, as evident in Hershkovitz (2006), Ogburn and Edwards (2015), and Hancock et al. (2018). The nucleosome data supports a sister relation with Montiinae, whereas the plastome data supports a sister relation with Lewisia. Also, despite its derived position in Montieae, patristic genetic distances of Lewisiopsis from its nearest common node with Cistantheae approximates that of Cistanthe and is much less than that of its Montioideae relatives. This pattern is shared with both plastome and nucleosome data, including the 297-loci largely nucleosome data set of Hancock et al. (2018). Thus, both morphological and molecular evolution of Lewisiopsis seems to have been sequestered. This explains its morphological similarities to the much earlier diverging Cistantheae (see also below) and helps explain its inclusion in Cistanthe based on morphological cladistic analysis.

1B. Calandrinia Kunth (nom. cons.), Humb., Bonpl. \& Kunth, Nov. Gen. Pl. (fol. ed.) 6: 62. 1823; type: C. ciliata (Ruíz \& Pav.) DC. (nom. cons.) $\equiv$ Talinum ciliatum Ruíz \& Pav. = Cosmia Dombey ex Juss., Gen. P1. 312. 1789., obs.

= Baitaria Ruíz \& Pav., Fl. Peruv. Prodr. 63. 1794.

= Geunsia Moc. \& Sessé ex DC, Prodr. 3: 358. 1828, nom. inval.

= Phacosperma Haw., Philos. Mag. Ann. Chem. 2 (1): 123. 1827.

= Monocosmia Fenzl, Nov. Stirp. Dec. 84. 1839.

The current cladistic circumscription of Calandrinia was proposed in Hershkovitz (1990b), based on intuitive interpretation of morphology. The circumscription differed from the previous (and first) cladistic circumscription, which classified the annual species in this genus, but classified the perennial species in Baitaria, along with all species of Montiopsis (Carolin, 1987, 1993). Monophyly of the current circumscription has been confirmed by all five subsequent molecular analyses cited in this work, including Hancock et al. (2018), who proposed a different circumscription (see below). But because Calandrinia was the conserved name for the classical concept of Calandrinia s. 1., some confusion has persisted. The generic name was bound to persist. If the cladistic classification included NO species in Calandrinia, its assimilation would have been faster and easier. 
Calandrinia s. 1. is an example of a classical so-called "evolutionary" taxon. These were conceptually fundamentally Aristotelian (Scala Natural) in that taxa were conceived hierarchically according to their perceived degree of evolutionary specialization. "Higher" or "advanced" taxa emerged from "lower" or "primitive" taxa (e.g., "lower vascular plants"), the latter cladistically paraphyletic. Segregation of perceptually specialized advanced taxa left taxonomic receptacles to which were relegated more perceptually primitive taxa. Calandrinia s. 1. was such a receptacle. It was not, nor intended to embody, a monophyletic taxon. It was the receptacle for largely western American and Australian species with most or all of the following traits: hemicryptophytic herbs, hypogenous flowers, conspicuous corolla of five petals, five stamens, three carpels, and a basipetally dehiscent valvate capsule with many seeds. Otherwise, the species were morphologically heterogeneous and classified into 12 American and six Australian sections (Carolin, 1987, 1993). The traits were not good indicators of relationship. For example, achenial species segregated into their other genera and even classified in different classical tribes (McNeill, 1974) proved to be otherwise morphologically and genetically very closely related to certain Calandrinia s. 1. species.

Apparent taxonomic confusion following the cladistic dissection of Calandrinia s. 1. owes to several factors. One was the historical fact that, at the time, much, if not most, of the plant taxonomic community did not embrace or yet understand the emerging paradigm of cladistics and/or the logic of cladistic taxonomy. Many new research and reference works continued to apply the classical classification.

Another factor was the failure to appreciate that the cladistic realignments divided Calandrinia s. 1. along existing sectional lines. Clusters of sections were segregated as or integrated into other genera. Thus, the cladistic classification, while not conserving existing genera, did conserve existing taxa. In fact, on morphological bases, the cladistic taxonomy was far more self-evident than the prior taxonomy, because several sections intergraded morphologically within their clusters. Cladistically clustered, their morphological distinctions were unambiguous. However, in scientific practice, taxonomy emphasizes only genus and species and not intervening ranks. To non-specialists unfamiliar with the sectional taxonomy, the cladistic classification was less comprehensible.

Another factor was "taxonomic provincialism." Regional floristic taxonomists historically tended to perceive, hence classify, new taxa in a local rather than global context. Sometimes, workers simply were unfamiliar with global diversity of local higher taxa. For example, a few species of South American and Australian Montiaceae described as Calandrinia s. 1. proved to be species of Phemeranthus, Talinum (Talinaceae), or Anacampseros (Anacampserotaceae). But regional specialists classified them in the regionally predominant Calandrinia s. lato.

A final exacerbating factor may have been the long delay in transferring species to their new genera. Roger Carolin had prepared but never published catalogs of binomial recombinations according with his cladistic classification. These catalogs recombined all existing typified binomials, whether or not the corresponding species were taxonomically accepted. I believed that half or more of these recombinations effectively created new taxonomic synonyms. But as I was primarily a higher taxon specialist, I urged my species taxonomy specialist colleagues to assume the recombination effort. For reasons articulated above, the process was delayed for several years. For my part, I recombined binomials only 
as necessary to refer to the corresponding (often misidentified) species in my phylogenetic work. Consequently, the taxonomy, especially of Cistanthe, persisted in a chaotic state, a haphazard mixture of new and old binomials and misidentifications. Naturally, this did not aid in appreciation of the cladistic generic distinctions. In retrospect, Carolin's approach was the more prudent.

Reflecting on the history of the transition between Calandrinia s. 1. and the cladistic taxonomy, one can appreciate that the purpose of scientific taxonomy is purely informatic, i.e., to help assure that names map to the same type and to promote understanding that types, and not taxa, are the reference point for all taxonomic usage. Thus, taxonomic nomenclatural codes regulate only the nomenclatural validity of scientific names, but not the ontological validity of taxa. The latter is supposed by a very few specialists. In broader usage, scientific names are learned and effectively common Latin names, their ontology not verified by the users. And, of course, one cannot "unpublish" older but still consulted references. Much like fixation of new alleles in populations, only with time do newer taxonomic names become fixed in the vernacular.

\section{B1. Calandrinia sect. Calandrinia}

= Calandrinia sect. Compressae Reiche, Ber. Deutsch Bot. Ges. 15: 502.1897.

$=$ Calandrinia sect. Axillares Reiche, Ber. Deutsch Bot. Ges. 15: 502. 1897.

Ca. seven annual species native to western America, distributed along the American cordillera nearly continuously from British Colombia to Tierra del Fuego (Hershkovitz, 2006). Calandrinia menziesii (Hook.) Torr. \& A. Gray is adventive on other continents/islands (Hershkovitz, 2006). Calandrinia compressa Schrad. ex DC is listed as adventive in Europe in several text and web references (not listed here), but its establishment status reports are conflicting. Possibly the reports reflect transitory escapes from cultivation. The species is established, however, in New Zealand (Howell and Sawyer, 2006).

1B2. Calandrinia sect. Acaules Reiche, Ber. Deutsch Bot. Ges. 15: $500.1897 \equiv$ Baitaria Ruíz \& Pav.; lectotype (designated here): C. acaulis Humb., Bonpl. \& Kunth non Baitaria acaulis Ruiz \& Pav. $\equiv$ Calandrinia carolinii Hershk. \& D. I. Ford.

Ca. 10 perennial species of western South America, one extending to Central America and southern Mexico (Hershkovitz, 2006; Elvebakk et al., 2015).

All five molecular analyses cited in this work indicate that this section is monophyletic, disproving the suggestion that it may be paraphyletic with respect to $C$. sect. Calandrinia (Hershkovitz, 1993).

1C. Hectorelleae Appleq., Nepokr. \& W. L. Wagner, Syst. Bot. 31: 316. 2006.

1C1. Hectorella Hook. f., Handb. N. Zeal. Fl. 27.1864; type: H. caespitosa Hook. f. 
One perennial species of New Zealand (Applequist et al., 2006; Wagstaff and Hennion, 2006).

1C2. Lyallia Hook. f., Bot. Antarct. Voy. Antarct. (F1. Antarct.) 2: 548, t. 122. 1847; type: L. kerguelensis Hook. f.

One perennial species of the Kerguelen Islands (Applequist et al., 2006; Wagstaff and Hennion, 2006).

1D. Rumicastrum Ulbrich, Engler \& Prantl, Nat. Planzenfam. 16c: 519. 1934; type: $R$. chamaecladum (Diels) Ulbrich $\equiv$ Atriplex chamaeclada Diels.

= Calandrinia sect. Apicales Poelln., Repert. Spec. Nov. Regni Veg. 35. 1934.

= Calandrinia sect. Basales Poelln., Repert. Spec. Nov. Regni Veg. 35.1934.

= Calandrinia sect. Tuberosae Poelln., Repert. Spec. Nov. Regni Veg. 35. 1934.

= Calandrinia sect. Partitae Poelln., Repert. Spec. Nov. Regni Veg. 35. 1934.

= Calandrinia sect. Pseudo-dianthoideae Poelln., Repert. Spec. Nov. Regni Veg. 35. 1934.

= Calandrinia sect. Uniflorae Poelln., Repert. Spec. Nov. Regni Veg. 35. 1934.

= Parakeelya Hershk., Phytologia 84: 101. 1999 [1998].

About 74 annual and perennial species of Australia, about 25 not yet described (Hancock et al., 2018; Thiele et al., 2018). All described species except $R$. chamaecladum (Diels) Ulbrich are currently erroneously classified as Calandrinia Kunth, most also with combinations in Parakeelya (Hershkovitz, 1998b, 2002; Thiele et al., 2018).

Hancock et al.'s (2018) analysis reveals partial agreement between phylogeny and classical sectional divisions, but also ambiguous relations in portions of the tree. The work also shows that perenniality evolved three times in this genus with no reversals.

Thiele et al. (2018) have published a proposal to conserve the generic name Parakeelya [lectotype: P. ptychosperma (F. Muell.) Hershk. $\equiv$ Calandrinia ptychosperma F. Muell.] against Rumicastrum. Seddon (2005) described how he first diagnosed Rumicastrum chamaecladum (Diels) Ulbrich (三Atriplex chamaeclada Diels) as Calandrinia s. 1. and not Chenopodiaceae. The latter classification owes, no doubt, to the fruit, which is achenial rather than capsulate. A mature specimen, lacking the ephemeral perianth and stamens and enclosed by its two sepals, indeed would resemble a female Atriplex flower, atepalous and enclosed by two deltoid bracts. Roger Carolin corroborated the finding (Carolin, 1987, 1993; Seddon, 2005) and thus planned to transfer all Australian species of Calandrinia s. 1. to Rumicastrum, and he drafted a manuscript accordingly. He retired in 1986 and sent me a copy of this manuscript.

In my work, e.g. (Hershkovitz, 1993), I trusted Carolin's diagnosis of Rumicastrum. But I had no need for a taxonomic combination in this genus until submitting my molecular phylogenetic analysis of cactus origins (Hershkovitz and Zimmer, 1997) for publication. That work sampled an Australian calandrinia. In the original journal submission, I provided a new combination for the sampled species in Rumicastrum. However, the journal editor, Werner Greuter (B), disputed this classification. Although the type specimen is believed to have been destroyed, he insisted that a conspecific specimen in B was "perfectly good 
Chenopodiaceae" and had "nothing whatsoever to do with Portulacaceae." Greuter, therefore, would not permit me to use the name Rumicastrum in my publication.

I had had no means of verifying Greuter's claim, but I could not delay this publication in order to resolve a peripheral taxonomic question. Therefore, I applied a new generic name, Parakeelya. I learned recently that this is the same name Carolin planned to use before diagnosing the identity of Rumicastrum (Seddon, 2005). In 1999 (i.e., nearly 20 years ago), Judy West (CANB) advised me that Carolin's diagnosis was correct, and that I had erred.

West and other knowledgeable Australian botanists now long have agreed that Rumicastrum chamaecladum is an Australian species of classical Calandrinia s. 1., and that transfer of the remaining species was inevitable, e.g., (Richardson, 1998). But they continued to classify the species in the genus Calandrinia - all except for one: Rumicastrum chamaecladum, for which no such combination in Calandrinia existed and none was proposed. Instead, between 2006-2017, 13 new species were described as Calandrinia (Obbens, 2006, 2012; Syeda and Carolin, 2011; West and Chinnock, 2013; Obbens et al. (2017). The generic concept of Calandrinia in these works is not clear. Syeda \& Carolin (2011) described the genus as comprising "about 100 species." At that time, there were perhaps about 55 recognized species in Calandrinia and Rumicastrum combined. The inclusion of Carolin as author was surprising, since he had advocated Rumicastrum. Carolin himself does not appear to have pronounced on the matter since his 1993 synopsis (Carolin, 1993), which was prepared before his retirement in 1986.

Hancock et al. (2018) circumscribed Calandrinia as comprising this genus plus Rumicastrum. This circumscription, which the same work rejects, appears to be ad hoc. It has no precedent and was not supported (though not unequivocally refuted) by prior evidence. The circumscription appears to reflect nomenclatural expedience. In particular, the authors knew (and had known for more than two decades) that Rumicastrum was the correct name for the Australian plants.

But they argued that existing evidence did not prove that Rumicastrum was not sister to Calandrinia. A sister relation would justify, on phylogenetic taxonomy criteria, the continued classification of Rumicastrum species as Calandrinia. Another possibility was that the peculiar R. chamaecladum would figure outside of this clade. Their analysis rejected both possibilities. They thus sought to conserve the name Parakeelya, which, pending its resolution, remains incorrect. Unable to use Parakeelya and unwilling to use Rumicastrum, they continued to use Calandrinia. It is for this reason that the authors obliged themselves to circumscribe Calandrinia thusly and then reject the circumscription.

But even if these genera formed a clade, their demonstrated morphological, genetic, and biogeographic divergence rendered senseless, even misleading, their merging. To appreciate this, had the Australian plants been described initially as a new genus and never classified in Calandrinia s. 1., there would seem to have been no reasonable basis (or motive) for then merging said genus with Calandrinia, even if the resulting genus were monophyletic, and much less so in a paper that proved that the thusly merged genus is not monophyletic.

2. Cistantheae Hershk., tax. nov.; lectotype (designated here): Cistanthe Spach, Hist. Nat. Veg. 5: 229. 1836. 
2A. Cistanthe Spach, Hist. Nat. Veg. 5: 229. 1836; lectotype (designated here): $C$. grandiflora (Lindl.) Schltdl. (nom. cons.) $\equiv$ Calandrinia grandiflora Lindl. $\equiv$ Cistanthe grandiflora (Lindl.) Carolin ex Hershk. (nom. superfl.) $\equiv$ Claytonia grandiflora (Lindl.) Kuntze $=$ Tegneria Lilja, Fl. oefver Sver. Odl. Vext.76. $1839 \equiv$ Rhodopsis Lilja, Fl. Sverig. Suppl. 1: 42. 1840; lectotype (designated here): Calandrinia discolor Schrad. $\equiv$ Cistanthe discolor (Schrad.) Spach.

Current acceptance of the generic segregation of Cistanthe stems from Carolin's $(1987,1993)$ work. Combinations for these taxa transferred from Calandrinia s. 1. are provided in Hershkovitz (1991b, Ford-Werntz \& Peralta (2002), and Peralta \& FordWerntz in Zuloaga et al. (2007) and below.

The current cladistic circumscription of Cistanthe was proposed in Hershkovitz (2006), based on molecular analysis. This work demonstrated that the circumscriptions of Carolin (1987, 1993) and (Hershkovitz, 1990, 1991a, 1992, 1993), based on morphology, were paraphyletic. Ogburn and Edwards (2015) remarked that their molecular analysis demonstrated paraphyly of the1990 circumscription. But they failed to note that Hershkovitz (2006) had demonstrated this, and that their own circumscription of Cistanthe was identical to Hershkovitz (2006).

As I will elaborate elsewhere, current molecular evidence demonstrates that the numerous morphological similarities shared among sections of Cistanthe in the broader 1990 circumscription are symplesiomorphies, not convergences, that indeed reflect low genetic divergence among these taxa. Thus, these shared traits appear to reflect morphology prevalent in earliest Montiaceae, from which other genera have diverged markedly.

Taxonomy of the Chilean species of Cistanthe is problematic. The most recent taxonomic treatment is Reiche (1898), which is more than 120 years old. It was based substantially on work of Philippi, especially Philippi (1893a, b). Reiche (1898) clearly was frustrated by this genus, combining diverse related forms as polymorphic species and manifesting uncertainty regarding the status of others. Also, numerous species have been described since Reiche's (1898) treatment.

The taxonomic difficulty is understandable. The plants are succulent and, unless carefully prepared, make poor herbarium specimens. Especially older collections, including type specimens, often are degraded and/or fragmentary and incomplete. Another problem is that most described species are endemic to the arid zone of Chile, especially between Regions II-IV. Because of the ENSO effect, seasonal periodicity of rains ranges from about 10 years to literally forever. This renders difficult plant exploration across this $1000 \mathrm{~km}$ tract. Moreover, species distributions in this area behave differently from areas of denser vegetations, which create local biotic communities and niches. Also, the stressful environment presumably induces mutation, such that odd phenotypes might be collected once and never again. The principal constraint on growth is not so much morphological phenotype as it is adequacy of moisture in the location where a seed happens to germinate. Finally, the strong moisture gradients across relatively short distances probably creates an unusual germplasm pool. In particular, in especially rainy years decades apart, the emerging plants represent correspondingly separated generations. Over historical time, the 
generational difference between plants in a single wet year can accumulate to thousands or more years.

Some problematic taxa are discussed below. No intention is made here to provide a revision, much less a monograph. The intention is merely to improve upon the existing, very old, and otherwise inadequate taxonomic reference and to facilitate future investigation. Any taxonomic clarification at all will aid in conservation efforts and in studies of phenotypic and ecological evolution, e.g., similar to Ogburn and Edwards (2015).

2A1. Cistanthe sect. Cistanthe $\equiv$ Calandrinia sect. Cistanthe Reiche, Ber. Deutsch Bot. Ges. 15: 501. 1897.

About 12 species, all but one perennial, primarily in Chile, one extending into San Juan Province, Argentina, and one endemic to Peru (Peralta, 1999; León, 2006).

Smith et al. (2018) and Hancock et al. (2018) demonstrated that the Peruvian $C$. paniculata (Ruíz \& Pav.) Carolin ex Hershk. pertains to this section. Some taxonomically necessary combinations are lacking and provided here. As in Hershkovitz (1990, 1991b), I attribute authorship to Roger Carolin, based on an unpublished manuscript he sent me in 1986. This recognizes especially Carolin's contribution to modern Montiaceae taxonomic and phylogenetic concepts.

Lectotypification here of Tegneria Lilja is for clarification. Lilja (1841) included in this genus Calandrinia discolor Schrad [= Cistanthe discolor (Schrad) Spach] and "Calandrinia speciosa," evidently Calandrinia speciosa Lehm. [= Cistanthe speciosa (Lehm.) Lilja ex Heyn.]. Both of these species are included in Reiche's $(1897,1898)$ Calandrinia sect. Cistanthe as possible taxonomic synonyms of Cistanthe grandiflora (see below). But Lilja also included a later homonym, Calandrinia speciosa Lindley (三 Calandrinia elegans Spach = Calandrinia menziesii (Hook.) Torr. \& A. Gray; cf. Reiche (1897, 1898). Lilja evidently did not appreciate that the homonymous plants were distinct [see (Steudel, 1840: 253), cited by (Lilja, 1841)].

I provide below taxonomically necessary combinations:

Cistanthe aegitalis (Phil.) Carolin ex Hershk., comb. nov. $\equiv$ Calandrinia aegitalis Phil., Anales Univ. Chile 85: 184. 1893.

Cistanthe crassifolia (Phil.) Carolin ex Hershk., comb. nov. $\equiv$ Calandrinia crassifolia Phil., Anales Univ. Chile 85: 180. 1893.

Cistanthe mucronulata (Meyen) Carolin ex Hershk., comb. nov. $\equiv$ Calandrinia mucronulata Meyen, Reise Erde 1: 314. 1834.

Although taxonomically troublesome, several Chilean species of $C$. sect Cistanthe seem to be morphologically diagnosable, especially the high altitude and more southerly taxa. Taxonomy of plants of the Atacama Desert of Regions II-III of Chile remains more problematic. Nominally species-level DNA sequence markers failed to aid in species diagnostics (Hershkovitz, 2006). Genotypes were shared haphazardly among multiple morphologically distinct and geographically divergent forms. 
Below is an annotated descriptive list of putatively distinct species in Chile, with the distinguishing features italicized. The list in no way is intended as a formal taxonomic/floristic revision. Nonetheless, evidently it provides the only attempted summary of the Chilean species since Reiche (1898). It is intended to assist further investigation.

1. Cistanthe mucronulata (Meyen) Carolin ex Hershk. (?= Calandrinia spectabilis Otto \& A. Dietr.; see below): the only species of the precordillera and coast ranges of Chile Regions VI-VII, often found along roadcut cliffs. The type locality is the vicinity of San Fernando (Region VI). Perennial, inflorescence/flowers similar to C. discolor but leaves not correspondingly coriaceous or bicolored, blades often rotund. An especially large and more succulent form occurs on the beaches at Constitución. Vegetatively, it superficially resembles $C$. laxiflora, but otherwise conforms to the species.

2. Cistanthe discolor (Schrad.) Spach: the only precordillera species of Chile Regions IV, V, northernmost VI, and Metropolitana, approaching the coast at higher elevations in Region IV, e.g., near Andacollo. Perennial, plants not glaucous, leaves coriaceous, green abaxially, paler along the major veins, purplish adaxially, inflorescence culms terete, stamens about 50, style and stamen height equal. The type was cultivated from seed. The original description of the leaf coloration provides its principal diagnosis.

3. Cistanthe grandiflora (Lindley) Schltdl., nom. cons. [ $=$ C. glauca (Schrad.) Lilja]: coastal regions from Chile Region III-V, possibly also in Region II, extending as a ruderal to the precordillera from northernmost Region V to southern Region III, possibly naturalized elsewhere in Chile and Argentina. Weedy, usually glaucous perennial (sometimes annual?) up to $2 \mathrm{~m}$ in height; erect, strict (smaller plants) to highly branched, larger plants somewhat suffruticose; branches leafy below, terminating in usually 2-3branched inflorescences, culms becoming sharply angular or fasciated distally, stamens about 50, style and stamen height equal.

The size of larger plants suggests the plants are perennial (as indicated in the original diagnosis), but I have not verified this by perennial monitoring tagged individuals. I have observed small plants flowering in their first year. In drought conditions, these may behave as annuals. Alternatively, $C$. grandiflora might be a species complex with otherwise similar perennial and annual forms.

Perennial, more suffruticose plants with more coriaceous and only (supra-)basal leaves of coastal and interior Region III Atacama Desert flats have the angled inflorescence and floral traits of $C$. grandiflora. I believe that they represent a distinct species (or hybrid), but I cannot confirm their identity. Cistanthe speciosa emerges as a candidate, but its diagnosis indicates terete culms (see also below).

I believe that "Calandrinia taltalensis I. M. Johnst." of Region II fits within the range of variation of $C$. grandiflora. If a distinct taxon, it is most closely related to this species. I emphasize that the species is morphologically variable even in the Mediterranean climate zone, hence this plasticity ought to manifest even more so in the hyperarid zone.

Plants I carelessly misnamed C. discolor in [20] are actually C. grandiflora as described here, as might be evident from their collecting localities.

Veldcamp (2015; cf. Applequist, 2016) presented evidence that, contrary to what historical literature would suggest (Schlectendal, 1831), Calandrinia glauca Schrad. [三 
Cistanthe glauca (Schrad.) Lilja], was validly named prior to Calandrinia grandiflora Lindley [ $\equiv$ Cistanthe grandiflora (Lindley) Schltdl. Because these names generally are considered heterotypic synonyms, $C$. glauca should have priority. Conservation of the name $C$. grandiflora is based on historical preponderance of its application.

4. Cistanthe sp. n.: coastal range valleys, coastal terraces, and beaches, Chile Regions (II? -)IV-V; annual, leaves (supra-)basal, strict to sparsely branched bracteates inflorescences less than $50 \mathrm{~cm}$ high; culms terete; petals 1-3 cm long, stamens about 30 , stigma much lower than to about the same height as the stamens. This taxon includes the plants described and illustrated as C. grandiflora in Villagrán et al. (2007), based on my erroneous diagnosis. My identification of the annual plants as $C$. grandiflora based purely on deduction. As I could account for the identities of $C$. glauca and C. laxiflora, $C$. grandiflora was the only remaining name for plants from this geographic range. I failed to verify the diagnosis of $C$. grandiflora, which indicates suffrutescence. Yet, there clearly is a distinct and definitely annual species in the range shared with $C$. grandiflora and $C$. laxiflora.

There are three forms of the annual species. Whether this variation represents plasticity is not clear. One is an uncommon and more or less prostrate and more succulent form that occurs among herbaceous beach vegetation, e.g., at Zapallar and Huaquén [illustrated in Villagrán et al. (2007)]. Another is a more erect and less succulent form with identical flowers very uncommonly found in low drier sites from the coast to interior valleys of Region V and the Metropolitana Region. Collections 99-945 and 99-977 misidentified as C. grandiflora in Hershkovitz (2006) are of this form. The third form comprises somewhat larger plants common during rainy years on the sandy coastal plains between Ovalle and Coquimbo (Region V). Collection 00-144 misidentified as $C$. grandiflora in Hershkovitz (2006) is this form. The flowers are larger and stigma height equals the stamens. These plants are absent drought years, but in rainy years, some populations rival in aspect the carpets of Cistanthe longiscapa (Barnéoud) Carolin ex Hershk. of the "desierto florido."

As noted above, Reiche (1898) formally recognized only a polymorphic $C$. grandiflora in his Calandrinia sect. Cistanthe (三 Cistanthe sect. Cistanthe). He briefly discussed other named species informally. For a century thereafter, many authors and collectors worldwide, including myself (Hershkovitz, 1991a, 1991b,1992), commonly identified any/all individuals of $C$. sect. Cistanthe as $C$. grandiflora. The confusion mainly owes to the poor preservation of herbarium specimens, these often just an inflorescence branch and a few moldy or broken leaves. In the field, the species of $C$. sect. Cistanthe are remarkably distinct, since they range from annuals to pachycaul shrubs.

It is remarkable that a locally common and conspicuous annual species of $C$. sect. Cistanthe has been overlooked throughout two centuries of Chilean botanical exploration. Possibly, as in Hershkovitz (2006), the plants were known but misidentified because of the historical taxonomic ambiguity/confusion within $C$. sect. Cistanthe and poor specimen preservation. The oversight probably owes also to its infrequency in the moister southern portion of its range, and the infrequency of adequate precipitations sufficient to spawn the larger and more conspicuous Region IV populations.

5. Cistanthe laxiflora (Phil.) Peralta \& D. I. Ford: coastal cliffs and outcrops, Chile Regions IV-V (ca. Cartegena to just south of Fray Jorge); perennial with leafy erect to 
scandent stems to $2 \mathrm{~m}$, culms terete, petals $3-5 \mathrm{~cm}$ long, usually magenta but ranging from rose to violet in some populations, stamens about 75, style prominently exserted, about twice as high as the stamens. Because of its large size and unique coastal niche, this is perhaps the most conspicuous and recognizable species of $C$. sect. Cistanthe. Based on the original description, type locality (Concón; Region V, Chile), and the type specimen in SGO, its identity is not in doubt.

6. Cistanthe aegitalis (Phil.) Carolin ex Hershk.: beaches in the vicinity of Fray Jorge and Talinay, Chile Region IV; perennial, suffruticose with (supra-)basal coriaceous leaves, stem leaves markedly reduced to bracteate, overall similar to C. crassifolia $200 \mathrm{~km}$ to the north but corollas with magenta centers and pale rose margins. The identity is not in doubt, as it is the only Cistanthe species at the type locality. The original description and type specimen in SGO match. I did not find C. laxiflora or C. glauca here.

7. Cistanthe crassifolia (Phil.) Carolin ex Hershk.: beaches and coastal bluffs of Chile Region III, Huasco to Totoral; perennial, suffruticose on beaches, but on bluffs developing into a pachycaul (sub-)shrub; corollas pink (southern populations) or white (northernmost populations). The original description, type locality, and type specimen in SGO render diagnosis unequivocal. My suggestion that the species grades into and includes low chamaephytic beach forms is novel and requires confirmation.

8. Cistanthe cabrerae (Cullen) Peralta: cordillera, Chile Region III to San Juan Province, Argentina; perennial with prominently amplexicaul leaves. The species is illustrated in Peralta (1993). Its diagnosis is not in doubt.

In addition to the above, there probably exist at least two other forms that will prove to merit acceptance as species. Muñoz (1985) illustrated a plant that she diagnosed as (effectively) Cistanthe speciosa (Lehm.) Lilja ex Heyn. Collection 00-91 in Hershkovitz (2006) is this form. Its distinctive features are its very large size and, especially, its bowlshaped corollas (resembling peonies) with pale pink petals and about 80 stamens. However, I cannot confirm its identity as $C$. speciosa. Other plants of desert valleys towards coastal Region II having flowers more similar to $C$. glauca also have been labeled as C. speciosa. Also, I have seen collections and photos of plants from Region II of Chile that bear numerous prostrate leafy branches with rhomboid leaves. These plants probably represent a distinct species. I cannot rule out that this is $C$. cachinalensis, described from this area.

2A2. Cistanthe sect. Rosulatae (Reiche) Hershk., comb. nov. $\equiv$ Calandrinia sect. Rosulatae Reiche, Ber. Deutsch Bot. Ges. 15: 502. 1897; lectotype (designated here): C. longiscapa (Barnéoud) Carolin ex Hershk. $\equiv$ Calandrinia longiscapa Barnéoud.

= Calandrinia sect. Arenarie Reiche, Ber. Deutsch Bot. Ges. 15: 502. 1897.

= Calandrinia sect. Andinae Reiche, Ber. Deutsch Bot. Ges. 15: 502. 1897.

At least 17 named annual and perennial species, primarily in Chile, four extending into Argentina (Peralta, 1999), one primarily in Peru but now collected in Chile, one endemic to Peru (León, 2006), and two in North America (Hershkovitz, 1991a). I also recognize 4-5 undescribed species. 
Taxonomy of Cistanthe, especially C. sect. Rosulatae, species is woefully inadequate and the most unsatisfactory and neglected of that of any Portulacineae genus, especially for reasons cited above. Also, I have observed in the field three "smoking gun" cases of interspecific hybridization, i.e., where the distinct parental species and their hybrid offspring occur together (Hershkovitz, 2006 and unpublished observations).

Hershkovitz' (2006) analysis indicates that $C$. sect. Rosulatae comprises two clades, which are here recognized as subsections.

2A2a. Cistanthe sect. Rosulatae (Reiche) Hershk. subsect. Rosulatae, tax. nov.

At least 12 species, including all species Reiche's $(1897,1898)$ Calandrinia sect. Andinae. The species are mainly Chilean, with a few extending into Argentina.

I provide here taxonomically necessary combinations:

Cistanthe chamissoi (Barnéoud) Carolin ex Hershk., comb. nov. $\equiv$ Calandrinia chamissoi Barnéoud in Gay, Fl. Chil. 2(4): 497-498. 1846 [1847] $\equiv$ Calandrinia arenaria var. chamissoi Reiche, Fl. Chil. 2:346. 1898 三 Claytonia chamissoi (Barnéoud) Kuntze, Rev. Gen Pl. 1 56: 1891. Holotype: Bertero 1348, “Quillota," Chile (P!).

The taxonomy of the Cistanthe arenaria (Cham.) Carolin ex Hershk. complex is perhaps the most intractable of all in the genus. Unlike $C$. sect. Cistanthe, the myriad and intergrading forms of the $C$. arenaria complex do not distinguish themselves well in the field, neither morphologically, nor geographically.

The $C$. arenaria complex includes both annual and perennial forms that might be described as "nondescript" among Cistanthe species in that the vegetative/floral morphological/geographic variation is intermediate/intergrading between extremes of the genus. None of their traits are the largest or smallest or most distinctive. Perhaps the most distinctive trait is the leaf shape in most forms. They range from linear to oblanceolate, but most plants have leaves differentiated into an apical rhomboidal blade or dilation that tapers basispetally, forming a broad petiole.

Difficulty of distinguishing between the annual forms was discussed by Philippi (1893a). Reiche (1898) included eight specific taxonomic synonyms under C. arenaria, which he described as annual and highly polymorphic (similar to his concept of $C$. grandiflora). He indicated that part of the taxonomic difficulty owed to the incompleteness of the type specimens. He recognized three varieties as distinct from the species, including C. chamissoi. Plants of the latter have more linear leaves and small flowers with five rather than numerous stamens.

Annual plants commonly encountered and commonly identified as $C$. arenaria are concentrated in inland valleys and hills in Chile's Regions IV-VI, 0-500 m. They can be weedy in ruderal or agricultural areas. Unfortunately, the type locality is in fluvial sands in coastal Region VIII. While the life history and root morphology were not described by Chamisso (1831), the short caudex/root fragment of the type specimen [Chamisso s. $n$., "II./III. 1816," "Concepción," Chile (Holotype (designated here): HAL!; isotype: K, photo!)] is $5-10 \mathrm{~mm}$ broad. Its leaf blades are broadly rhombic, about $10 \mathrm{~mm}$ broad. I have 
seen the described plants in this region and consider them to be perennial, though I also have considered them to be the same as or related to $C$. solisii (see below). In any case, the evidence indicates that none of the commonly annual encountered forms in Regions IV-VI are $C$. arenaria.

I have found in numerous localities throughout Chile's Region IV two annual forms growing side-by-side, easily distinguished by their linear leaves and small flowers versus broad leaves and large flowers. The former corresponds to C. chamissoi. I found only a single possible hybrid individual. In addition to the previously described traits, the stigma of $C$. chamissoi is pale, small, and capitate, whereas that of the so-called annual $C$. arenaria form is magenta, relatively larger, and conspicuously lobed and pubescent. The plants often grow together on cultivated or otherwise heavily disturbed ground. On less disturbed ground, the two species also tend to segregate, $C$. chamissoi preferring gray, limey substrate and so-called annual $C$. arenaria form preferring brownish, granitic substrate.

Cistanthe venulosa (Hook.\& Arn.) Carolin ex Hershk., comb.nov. $\equiv$ Calandrinia venulosa Hook. \& Arn., Bot. Misc. 3: 336. 1833. Holotype (designated here): Cuming 514, "Valparaiso" (K, photo!); syntype: Bridges s. n., "Valparaiso" (K, photo!).

Among the synonyms Reiche (1898) included in C. arenaria is $C$. venulosa. Given the characteristics of the evidently annual $C$. venulosa, along with the confused taxonomic identity of the evidently perennial $C$. arenaria, I revalidate its name. In my travels in Chile's Regions IV-V, I have found that annual plants of this complex generally are of the so-called annual $C$. arenaria form (rhombic leaf blades, large flowers) or the $C$. chamissoi form (linear leaves, small flowers). As evident from the type and description, Cistanthe venulosa has large flowers but narrowly linear leaves, hardly or at all dilated at the apex. I have seen such plants rarely, e.g., south of Chincolco, Region V (formerly Valparaiso Province), Petorca Province.

Cistanthe oblongifolia (Barnéoud) Carolin ex Hershk., comb. nov. $\equiv$ Calandrinia oblongifolia Barnéoud in Gay, Fl. Chil. 2(4): 482-483. 1846 [1847].

As I described in Hershkovitz (2006), I observed in the Cordillera Doña Ana (Region IV, Chile) fertile annual hybrids between the perennial C. oblongifolia and the annual $C$. humilis (Phil.) Peralta. The hybrids appear at the altitudinal border of their ranges. These hybrids thus present the potential for establishing a new hybrid species.

Cistanthe solisii (Phil.) Carolin ex Hershk., comb. nov. $\equiv$ Calandrinia solisii Phil., Anales Univ. Chile 85: 303.

C. solisii is perennial with a thick taproot and southerly distribution (Chile's Region VIII). It differs from its latitudinal neighbor C. fenzlii, in its less woody caudex and lower elevational range ( $<$ ca.200m versus $>$ ca. $500 \mathrm{~m}$ ). Additional investigation may reveal greater intergradations between these taxa. Calandrinia lancifolia Phil. from Angol (Region IX; base elevation ca. $200 \mathrm{~m}$ ) was described in the same publication as C. solisii, 
but it was described as being more woody at the base (Philippi, 1893a). Reiche (1898) included Calandrinia lancifolia in synonymy with C. fenzlii.

Philippi (1893) was perplexed by herbaceous plants he found and described at the type locality of Calandrinia spectabilis Otto \& A. Dietr., fluvial sands in coastal Region VIII. From its description as suffruticose with a $30 \mathrm{~cm}$ high stem, as well as its large organ dimensions (Otto and Dietrich, 1833) Calandrinia spectabilis seems to belong to Cistanthe sect. Cistanthe. There is no type specimen. Reiche (1898) listed it in synonymy with $C$. grandiflora, but the only plants of that section that conceivably could extend to Region VIII are the coastal succulent forms of $C$. mucronulata.

Although perplexed, Philippi evidently believed that the herbaceous plants were Calandrinia spectabilis, lest, no doubt, he would have described them as a distinct species. I have found in this region and habitat the same plants as Philippi described. I believed them to be maritime, hence not unexpectedly somewhat more succulent, forms of Cistanthe solisii. Philippi (1893b) did not mention these plants in his description of C. solisii.

A complication is that the locality of Philippi's plants is the same as the type locality of Cistanthe arenaria (see above). Certainly Philippi was aware of $C$. arenaria (Philippi, 1893a). While he had no access to the type specimen of $C$. arenaria, it is difficult to believe that he did not have Chamisso's (1831) publication in Linnaea. Philippi published in this same journal, had maintained a close correspondence with its editor, Schlectendal, and deposited many of his duplicates in HAL. Thus it seems that Philippi overlooked the type locality of $C$. arenaria, lest he would have realized that it was the same as the locality of the plants that puzzled him. Except for lacking a description of the life history and root, Chamisso's description otherwise is in good agreement with Philippi's.

If $C$. solisii is the same species as $C$. arenaria, the latter has priority. Indeed it is possible that $C$. fenzlii and its three heterotypic synonyms (Reiche, 1898) are all $C$. arenaria, and that common annual plants widespread in Regions IV-VI and identified as $C$. arenaria [following Reiche (1898)] all are other species.

2A2b. Cistanthe sect. Rosulatae (Reiche) Hershk. subsect. Thyrsoideae, subsect. nov.; lectotype (designated here): C. thyrsoidea (Reiche) Peralta and D. I. Ford $\equiv$ Calandrinia thyrsoidea Reiche.

Six annual species, including the Chilean Cistanthe thyrsoidea and $C$. cephalaphora, the North American C. maritima (Nutt.) Carolin ex Hershk. and $C$. guadalupensis (T.R. Dudley) Carolin ex Hershk., and probably the Peruvian C. lingulata (Ruíz \& Pav.) Hershk. I have seen an unaccessioned specimen from Region I of Chile.

Relations of the first three species is documented in Hershkovitz (2006). Inclusion of C. guadalupensis is based on inspection of an ITS sequence in Genbank (FJ614057.1). In the range of ITS1 base positions 70-80, all samples of this clade share a five-base motif, "C]TCCCT[C." This aligns with a three-base motif, "C]-CTC-[C," shared by all other samples of both sections of Cistanthe. I refer C. lingulata to this clade based on morphological resemblance to $C$. thyrsoidea. 
The South American species are relatively small herbs with very small flowers, and I have observed cleistogamy in $C$. thyrsoidea. The North American species have rather larger and showy flowers, and C. guadalupensis is a pachycaul shrub.

2B. Montiopsis Kuntze, Rev. Gen. Pl. 3(2): 14. 1898; type: $M$. boliviana Kuntze $\equiv M$. cumingii (Hook. \& Arn.) D. I. Ford $\equiv$ Calandrinia cumingii Hook. \& Arn.

Hancock et al.'s (2018) 297-loci phylogenomic analysis confirms the results of Ogburn and Edwards (2015) in placing Montiopsis within Cistantheae. The relations of Montiopsis were unresolved in Hershkovitz (2006). Interestingly, Hancock et al.'s (2018) Bayesian analysis of phylogenetic concordance among loci showed significant residual support for monophyly of Cistanthe with Calyptridinae, as in morphological analyses of Carolin (1987) and Hershkovitz (1991a, 1993). I hypothesize that this residual support reflects loci related to the morphological similarities of these taxa.

Hershkovitz' (1993) cladogram shows Montiopsis as sister to Calandrinia. However, he noted that this was supported only by the shared presence of trichomes, and that the trichomes were structurally very different. He also noted the gross similarity between the acaulescent Montiopsis (subg. Dianthoideae) cistiflora (Gillies ex Arn.) D. I. Ford and species of Calandrinia sect. Acaules. The former has a 1-3-flowered axillary inflorescence, and the latter is 1-flowered. However, he noted that inflorescence development and form of Montiopsis otherwise was distinct from Calandrinia and Cistanthe, resembling, if anything, more that of Lewisia sect. Cotyledon. Thus, current molecular evidence confirms that the distinctive morphology of Montiopsis reflects its marked evolutionary divergence, as evident in branch lengths in molecular phylograms of Hancock et al. (2018).

\section{B1. Montiopsis subg. Montiopsis}

= Calandrinia sect. Hirsutae Reiche, Ber. Deutsch Bot. Ges. 15: 502. 1897.

= Calandrinia sect. Condensatae Reiche, Ber. Deutsch Bot. Ges. 15: 503. 1897.

= Calandrinia sect. Parviflorae Reiche, Ber. Deutsch Bot. Ges. 15: 503. 1897.

= Calandriniopsis Franz, Bot. Jarhb. Syst. 42, Beibl. 97: 19. 1908.

Ca. 18 annual and perennial species, primarily in Chile, several extending into Argentina, one extending also into Bolivia (Ford, 1992).

Existing molecular data show (Hershkovitz, 2006) show no phylogenetic structure among these species.

2B2. Montiopsis subg. Dianthoideae (Reiche) D. I. Ford, Phytologia 74: 277. $1993 \equiv$ Calandrinia sect. Dianthoideae Reiche, Ber. Deutsch Bot. Ges. 15: 501. 1897; type: M. cistiflora (Gillies ex Arn.) D. I. Ford $\equiv$ Calandrinia cistiflora Gillies ex Arn.

At least four perennial species in Chile and Argentina (Ford, 1992). 
Molecular evidence (Hershkovitz, 2006; Ogburn and Edwards, 2015) demonstrates that this subgenus is monophyletic, defusing a suggestion by Hershkovitz (1993) that it might be paraphyletic with respect to $M$. subg. Montiopsis.

2C. Calyptridinae Hershk., tax. nov.; type: Calyptridium.

Except for the sister relation between Lenzia and remaining Calyptridinae, phylogenetic relations among the other two or three genera remain poorly resolved (Hershkovitz, 2006; Guilliams, 2009). Morphology and DNA weakly support monophyly of the bicarpellate species of Calyptridium. Monophyly of 2-3-carpellate Philippiamra is not well supported, but this owes to lack of molecular divergence among the taxa. Biogeography provides circumstantial evidence for monophyly of these genera. The problematic taxon is the three-carpellate Calyptridium/Thingia ambiguity, which, on biogeographic grounds, seems to be most likely sister to the two-carpellate Calyptridium. Existing molecular data cannot confirm this. The present work offers two solutions: classify this species in Calyptridium or segregate it into its own genus. The former seems preferable, because the divergence between these taxa evidently is much less than between other Montiaceae genera and even subgeneric taxa. Preference for the latter option conserves existing usage in the sense that the species conventionally was classified in Calandrinia s. lato, i.e., in a genus separate from Calyptridium.

On the basis of morphology, both Carolin (1987, 1993) and Hershkovitz (1990a, 1991a, 1993) classified Calyptridium and Philippiamra as sections of Cistanthe. Clarification of relations of the relations of Lenzia (Hershkovitz, 2006) and Montiopsis (Ogburn and Edwards, 2015; Hancock et al., 2018) defused this classification. As described above, however, the morphological similarities between these genera and Cistanthe appear to be symplesiomorphies and not convergences. Morphologically, Lenzia and Montiopsis are unique and highly divergent. Thus, the cladistic interpretation based on morphology is not surprising and, in a sense, is confirmed.

2C1. Lenzia Phil., Linnaea 33: 222. 1864; type: L. chamaepitys Phil. 2006).

One perennial species of Chile, Regions III and IV, above 3000 m (Hershkovitz,

As noted in Hershkovitz (2006), this peculiar acaulescent and evidently finely rhizomatous plant (Hershkovitz, 2006) bears no obvious morphological similarity to other Calyptridinae. I have never seen a flowering individual of this taxon, hence cannot verify the reported reproductive morphology (Reiche, 1898). The plant appears as a ca. $2 \mathrm{~cm}$ long cone of scarious-margined awl-shaped leaves. The mesophyll occupies only a thin central portion of the leaf. Found between 2500-3500 m on Andean slopes of Chile's Region IV, it evidently is resistant to extremes of both high and low temperatures and high (i.e., snowmelt) and low moisture.

2C2. Thingia Hershk., gen. nov.; lectotype (designated here): Thingia ambigua (S. Watson) Hershk., comb. nov. $\equiv$ Claytonia ambigua S. Watson, Proc. Amer. Acad. Arts 17: 
365(-366) $\equiv$ Calandrinia ambigua (S. Watson) Howell, Erythea 1:34. $1893 \equiv$ Cistanthe ambigua (S. Watson) Carolin ex Hershk., Phytologia 68: 269. 1990 E Calyptridium ambiguum (S. Watson) Hershk., comb. nov.

Plants annual, rosettiform with branched flowering branches, leaves succulent with three-dimensional leaf venation, the apical marginal veins connecting to form a "basket," inflorescence a sub-umbellate cincinnus, flowers many, pedicellate, subtended by a pair of markedly unequal scarious bracts, sepals 2 , petals 5 , stamens 5 , carpels 3 , fruit capsulate with 3 valves, seeds several, black, smooth, shiny, embryo nearly circular.

One species of the Mojave and Sonoran Deserts, Arizona, California, and adjacent northwestern Mexico (Guilliams, 2009).

Justification for this segregation is explained above. The generic name metaphorically refers to one of the colloquial name for the type species, "dead man's fingers" (SEINet, 2018). Thus, the genus is named for the literary figure, Thing, of the Addams Family cartoon, television series, and movie. Thing is an animated but (at least in the movie) disembodied human hand. This suggests that the hand derives from a deceased human, hence possesses a "dead man's fingers." Hershkovitz (1991c) described the threedimensional leaf venation. The generic combination also suggests an appropriate vernacular name, "ambiguous thing," reflecting the ambiguity of the status of this species following cladistic classification of Montiaceae.

2C3. Calyptridium Nutt. in Torr. \& A. Gray, Fl. N. Amer. 1(2): 198. $1838 \equiv$ Cistanthe sect. Calyptridium (Nutt. in Torr. \& A. Gray) Hershk., Phytologia 68: 267. 1990; type: $C$. monandrum Nutt. in Torr. \& A. Gray $\equiv$ Cistanthe monandra (Nutt. in Torr. \& A. Gray) Hershk.

= Spraguea Torr., Smithsonian Contr. Knowl. 6: 4. 1853.

About 12 annual and perennial species of western North America, mainly California, C. parryi A. Gray having four recognized allopatric varieties (Hinton, 1975; Guilliams, 2009; Guilliams et al., 2011; Guilliams and Miller, 2014).

Molecular data (Hershkovitz, 2006; Guilliams, 2009) confirm morphological evidence for monophyly of the three (one annual, two perennial) species once classified in Spraguea. Morphological evidence includes nonsucculence of the leaves, absence of planar leaf venation, and absence of the smaller of the two bracts subtending the flowers in other species. Molecular evidence confirms that perenniality is derived in Calyptridium. Although less clear, it is possible that the lower elevation and more ephemeral condition of C. monospermum Greene represent an evolutionary reversal from the alpine and longerlived condition of $C$. umbellatum (Torr.) Greene. These species hybridize and introgress in at least some locations along their ca. $1000 \mathrm{~km}$ contact zone (Hinton, 1975).

I provide here a taxonomically necessary combination: 
Calyptridium ambiguum (S. Watson) Hershk., comb. nov. $\equiv$ Claytonia ambigua S. Watson, Proc. Amer. Acad. Arts 17: 365(-366) E Calandrinia ambigua (S. Watson) Howell, Erythea 1: 34. 1893 E Cistanthe ambigua (S. Watson) Carolin ex Hershk., Phytologia 68: 269. 1990 三 Thingia ambigua (S. Watson) Hershk., comb. nov.

Justification for this combination is described above.

2C4. Philippiamra Kuntze, Rev. Gen. P1. 1: 58. 1891 Silvaea Phil., Fl. Atacam. 21. 1860 (non Silvaea Hook. \& Arn., Bot. Beech Voy. 211. 1837) ECistanthe sect. Philippiamra (Kuntze) Hershk., Phytologia 68: 269. 1990; lectotype (designated here): P. pachyphyllum (Phil.) Kuntze $\equiv$ Silvaea pachyphylla Phil. $\equiv$ Cistanthe pachyphylla (Phil.) Carolin ex. Hershk.

= Calandrinia sect. Amarantoideae Reiche, Ber. Deutsch Bot. Ges. 15: 501. $1897 \equiv$ Cistanthe sect. Amarantoideae (Reiche) Hershk., Phytologia 68: 269. 1990.

Perhaps 10 annual species of the Atacama Desert region, northern Chile, and adjacent San Juan Province, Argentina (Hershkovitz, 1991a; Peralta, 1999).

Taxonomy of the Philippiamra is even more difficult than that of Cistanthe, for the reasons cited above and more. The genus is distributed mainly in the hyperarid zone, Chile's Regions II and III, extending to the northern province of Region IV. The exploration difficulty posed by infrequent rain thus is exacerbated most. Also, the flowers are much smaller than those of Cistanthe. Because of their succulence, herbarium specimens often break and crumble.

Philippiamra includes both three-carpellate, capsulate, multiple-seeded species formerly classified in Calandrinia s. 1. and two-carpellate achenial species classified in Philippiamra. Existing molecular data do not discriminate between these groups (Hershkovitz, 2006). Both ribosomal and plastid genotypes are shared indiscriminately among both forms. The specimens in Argentina have been identified as Cistanthe densiflora (Peralta, 1999), but I have cultivated a specimen from seed. It is a distinct species, differing from $C$. densiflora in having leaves with firm texture, sharp-angled margins, deltoid shape, acute apex, and glossy luster, these traits similar to those of certain Echeveria DC (Crassulaceae) species. Leaves of $C$. densiflora have a spongy texture, oblanceolate shape, rounded apex, and matte luster.

I have observed that in E1 Nino "desierto florido" years, Philippiamra celosioides (Phil.) Kuntz is the last plant encountered when approaching the driest and rain-free sector of the Atacama Desert in Region II of Chile. Retreating from here, other Philippiamra species appear along with species of Cistanthe sect. Rosulatae. Thus, Philippiamra celosioides may be the world's most drought-tolerant ephemeral vascular plant.

According to Brummit (1993), Philippiamra replaced Silvaea Phil., which had been deemed a homonym with an earlier generic name, Silvia Benth. (Scrophulariaceae). Brummit reported that the nomenclatural committee deemed the two names distinct and concluded that "Silvaea should be adopted in Portulacaceae and Philippiamra should be regarded as a superfluous substitute." Strangely, no reference was made to another earlier generic name, Silvaea Hook. \& Arn. (Euphorbiaceae). The latter appears to be legitimate 
and valid (Webster, 1994), hence Silvaea Phil. remains homonymous and should be considered illegitimate.

I provide here taxonomically necessary combinations:

Philippiamra arancioana (Peralta) Hershk., comb. nov. $\equiv$ Cistanthe arancioana Peralta, Gayana Bot. 52: 45. 1995.

Philippiamra calycina (Phil.) Hershk., comb. nov. $\equiv$ Calandrinia calycina Phil., Fl. Atacam. 21. $1860 \equiv$ Cistanthe calycina (Phil.) Carolin ex Hershk., Phytologia 70: 220. 1991.

Philippiamra densiflora (Barnéoud) Hershk., comb. nov. $\equiv$ Calandrinia densiflora Barnéoud in Gay, Fl. Chil. 2(4): 503. 1846 [1847] = Cistanthe densiflora (Barnéoud) Carolin ex Hershk., Phytologia 70: 220. 1991.

Philippiamra minuscula (Cullen) Hershk., comb. nov. $\equiv$ Calandrinia minuscula Cullen, Bol. Soc. Arg. Bot. 5: 12. 1953 E Cistanthe minuscula (Cullen) Peralta in Kiesling, Fl. San Juan 1: 163. 1994

Philippiamra salsoloides (Barnéoud) Hershk., comb. nov. $\equiv$ Calandrinia salsoloides Barnéoud in Gay, Fl. Chil. 2(4): 502-503. 1846 三 Cistanthe salsoloides (Barnéoud) Carolin ex Hershk. in Phytologia 68: 269. 1990.

3. Phemerantheae Hershk., tax. nov.; type: Phemeranthus Raf.

3A. Phemeranthus Raf., Specchio Sci. 1: 86. 1814 = Talinum sect. Phemeranthus (Raf.) DC., Prodr. 3: 356. 1828; type: P. teretifolium (Pursh) Raf. $\equiv$ Talinum teretifolium Raf.

About 25 perennial species, mainly in North American, one in Argentina (Price, 2012). Phemeranthus confertiflorus (Greene) Hershk. is adventive in Europe (Nagodă et al., 2013).

Phemeranthus is sister to remaining Montiaceae (Ogburn and Edwards, 2015; Hancock et al., 2018). Its largely North American distribution is intriguing. All Portulacineae outgroups of Montiaceae appear to have southern hemisphere origins, as do other early diverging Montiaceae. Thus, Phemeranthus may have waifed to North America prior to the diversification of remaining Montiaceae. Phylogenetic relations among the species remain resolved (Price, 2012). Interestingly, the Argentinean species diverges early in the cladogram. The question of Phemeranthus origins may rest upon the relations of the Argentine-endemic Schreiteria (see below).

3B. Schreiteria Carolin, Parodiana 3: 330. 1985; type: S. macrocarpa (Carolin) Speg. $\equiv$ Calandrinia macrocarpa Speg.

One species of Argentina.

Carolin's (1987) analysis found the monotypic Schreiteria to be sister to Talinum s. stricto. The leaf venation is three-dimensional and the leaf base is pseudo-clasping, as in all species of Phemeranthus (Hershkovitz, 1991c; Ogburn and Edwards, 2013). The essentially 
sessile leaf is prominently constricted at the base into a miniscule petiole. A false clasping leaf base is formed by basal extension of the succulent leaf blade. These traits characterize species of Phemeranthus.

\section{Incertae sedis}

portulacoides Phil.

Diazia Phil., Fl. Atacam. 22. 1860. Lectotype (designated here): D.

Based on the protolog and illustration, I cannot diagnose the genus or even family of Diazia [cf. Reiche (1898: 499)].

\section{Acknowledgement}

Elaboration of the present work would not have been possible except for the generous support and dedicated efforts of Katia Chechelnitzky, Sandra Steuermann, and Gabriela Feldman of Fundación Reshet in Chile (www.reshet.cl). I gratefully acknowledge Mary Endress for helpful review and suggestions of an earlier incarnation of this work.

\section{References}

Applequist WL (2016). Report of the nomenclatural committee for vascular plants: 68 . Taxon 65: 1153-1165. https://doi.org/10.12705/641.12

Applequist WL, Wagner WL, Zimmer EA, Nepokroeff M (2006). Molecular evidence resolving the systematic position of Hectorella (Portulacaceae). Syst Bot 31: 310319. https://doi.org/10.1600/036364406777585900

Atlas of Living Australia (2018). Website:

https://biocache.ala.org.au/occurrences/search?q=\&fq=\&pageSize=100\&taxa=claytonia [accessed 28 July 2018].

Brummitt RK (1993). Report of the committee for Spermatophyta, 38. Taxon 43: 687-697. http://www.jstor.org/stable/1222553

Carolin RC (1987). A review of the family Portulacaceae. Austral J Bot 35: 383-412. https://doi.org/10.1071/BT9870383

Carolin RC (1993). Portulacaceae In: Kubitzki K, Bittrich V, Rohwer J, editors. The Families and Genera of Vascular Plants, Vol. 2. Berlin, Heidelberg, New York: Springer, pp. 544-555.

Chamisso A (1831). De plantis in expeditione Romanzoffianaobservatis disserere pergitur: Arcticae, quae supersunt. Linnaea : 545-583. https://www.biodiversitylibrary.org/item/10850

Davidson R. Lewisias. Portland, OR, USA: Timber Press; 2000.

Dembicz I, Łukasz K, Zaniewski PT(2015). Current state, habitat and potential invasiveness of Montia linearis (Douglas ex Hook.) Greene in Poland. Acta Soc Bot Poloniae 84: 347-356. https://doi.org/10.5586/asbp.2015.028

Elvebakk A., Flores AR, Watson JM (2015). Revisions in the South American Calandrinia caespitosa complex (Montiaceae). Phytotaxa 203: 91-23. 
https://www.researchgate.net/profile/Arve_Elvebakk/publication/281398515_Revisi ons in the South_American_Calandrinia caespitosa_complex_Montiaceae/links/5 6715b2f08ae2b1f87aee889/Revisions-in-the-South-American-Calandriniacaespitosa-complex-Montiaceae.pdf

Ford[-Werntz] DI (1992). Systematics and Evolution of Montiopsis subgenus Montiopsis (Portulacaceae). PhD dissertation, Washington University, St Louis, MO, USA.

Ford-Werntz D[I.], Peralta I[E] (2002). Cistanthe. In: Eggli U, editor. Illustrated Handbook of Succulent Plants: Dicotyledons. Berlin, Heidelberg, New York: Springer, pp. 380-6.

Francis JE, Marenssi S, Levy R, Hambrey M, Thorn VT, Mohr B, Brinkhuis H, Warnaar J, Zachos J, Bohaty S, DeConto R (2009). From greenhouse to icehouse - the Eocene/Oligocene in Antarctica. In: Florindo F, Siegert M, editors. Developments in Earth and Environmental Sciences, Vol. 8. Oxford: Elsevier, pp. 311-372. https://doi.org/10.1016/S1571-9197(08)00008-6

Franz NM, Sterner BW (2017). To increase trust, change the social design behind aggregated biodiversity data. Database (2017) Vol. 2017: bax 100 https://doi.org/10.1093/database/bax100

Guilliams CM, Miller JM (2014). Calyptridium. In: Jepson Flora Project, editors. Jepson eFlora. Revision 2. Website: http://ucjeps.berkeley.edu/eflora/eflora display.php?tid=68199 [accessed 22 July 2018].

Guilliams CM, Simpson MG, Rebman JP (2011). Calyptridium parryi var. martirense (Montiaceae), a new taxon endemic to Sierra de San Pedro Mártir, Baja California, Mexico. Madroño 58: 258-266. https://doi.org/10.3120/0024-9637-58.4.258

Guilliams CM. Phylogenetic Reconstruction, Character Evolution, and Conservation in the Genus Calyptridium (Montiaceae). Masters thesis, San Diego State University. http://www.sci.sdsu.edu/plants/lab/Guilliams2009-ThesisCalyptridium-Montiacr.pdf

Hancock LP, Obbens F, Moore AJ, Thiele K, de Vos JM, West J, Holtum JAM, Edwards EJ (2018). Phylogeny, evolution, and biogeographic history of Calandrinia (Montiaceae). Amer J Bot 105: 1-14. https://doi.org/10.1002/ajb2.1110

Heenan, PB (2007). New combinations in Montia (Portulacaceae). N Zeal J Bot 45: 437-

439. https://doi.org/10.1080/00288250709509725

Hernández-Ledesma P, Berendsohn WG, Borsch T, von Mering S, Akhani H, Arias S, Castañeda-Noa I, Eggli U, Eriksson R, Flores-Olvera H, et al. (2015). A taxonomic backbone for the global synthesis of species diversity in the angiosperm order Caryophyllales. Willdenowia 45: 281-383. https://doi.org/10.3372/wi.45.45301

Hershkovitz MA (1989). Phylogenetic studies in Centrospermae: a brief appraisal. Taxon 38: 602-608.

Hershkovitz MA (1990a). Nomenclatural changes in Portulacaceae. Phytologia 68: 267270. https://doi.org/10.5962/bhl.part.5799

Hershkovitz MA (1990b). Phylogenetic and Morphological Studies in Portulacaceae. PhD Dissertation, University of California/Davis. 
Hershkovitz MA (1991a). Phylogenetic assessment and revised circumscription of Cistanthe Spach (Portulacaceae). Ann Missouri Bot Gard 78: 1009-1021. http://www.jstor.org/stable/2399741

Hershkovitz MA (1991b). Taxonomic notes on Cistanthe, Calandrinia, and Talinum. Phytologia 70: 209-225. https://www.biodiversity.org/page/12983019

Hershkovitz MA (1991c). Leaf morphology of Cistanthe Spach (Portulacaceae). Ann Missouri Bot Gard. 78: 1022-1060. http://www.jstor.org/stable/2399742

Hershkovitz MA (1992). Leaf morphology and taxonomic analysis of Cistanthe tweedyi (nee Lewisia tweedyi; Portulacaceae). Syst Bot 17: 220-238. http://www.jstor.org/stable/2419519

Hershkovitz MA (1993). Revised circumscription and sectional taxonomy of Calandrinia Kunth and Montiopsis Kuntze (Portulacaceae) with notes on phylogeny of the portulacaceous alliance. Ann Missouri Bot Gard 80: 333-365. http://www.jstor.org/stable/2399789

Hershkovitz MA (1998a). Montia linearis (Douglas) E Greene (Portulacaceae) in Maryland. J Torrey Bot Soc 26: 350-351.

Hershkovitz MA (1998b). Parakeelya: a new genus segregated from Calandrinia (Portulacaceae). Phytologia 84: 98-106. https://www.biodiversity.org/page/13071596

Hershkovitz MA (2002). Parakeelya. In: Eggli U, editor. Illustrated Handbook of Succulent Plants: Dicotyledons. Berlin, Heidelberg, New York: Springer, pp. 394-400.

Hershkovitz MA (2006). Evolution of western American Portulacaceae in the Andean region. Gayana 63: 13-74. http://dx.doi.org/10.4067/S0717-66432006000100002

Hershkovitz MA, Arroyo MTK, Bell C, Hinojosa LF (2006). Phylogeny of Chaetanthera (Asteraceae: Mutisieae) reveals both ancient and recent origins of the high elevation lineages. Mol Phylogen Evol 41: 594-605. https://doi.org/10.1016/j.ympev.2006.05.003

Hershkovitz MA, Hogan SB (2002). Lewisia. In: FNA Committee, editors. Flora of North America North of Mexico, Vol. 3. New York: Oxford University, pp. 476-485.

Hershkovitz MA, Zimmer EA (1997). On the evolutionary origins of the cacti. Taxon 46: 217-242. http://www.jstor.org/stable/1224092

Hershkovitz MA, Zimmer EA (2000). Ribosomal DNA evidence and disjunctions of western American Portulacaceae. Mol Phyl Evol 15: 419-439. https://doi.org/10.1006/mpev.1999.0720

Hinton WF (1975). Systematics of the Calyptridium umbellatum complex (Portulacaceae). Brittonia 27: 197-208. https://doi.org/10.2307/2805891

Howell CJ, Sawyer JWD (2006). New Zealand Naturalised Vascular Plant Checklist.

Wellington NZ: New Zealand Plant Conservation Network.

León B (2006). Portulacaceae endémicas del Perú. Rev Peruana Biol 13 Suppl 2: 577s578s. https://dialnet.unirioja.es/descarga/articulo/2292185.pdf

Leonelli S (2013). Classificatory theory in biology. Biol Theory 7: 338-345. https://doi.org/10.1007/s13752-012-0049-z

Lilja N (1841). Observationes nonnullae botanicae circa nova quaedam genera. Linnaea 15: 259-265. https://www.biodiversity.org/item/10859 
Livermore R, Hillenbrand C-D, Meredith M, Eagles G (2007). Drake passage and Cenozoic climate: an open and shut case? Geochem Geophys Geosyst 8: Q01005. https://doi.org/10.1029/2005GC001224.

Mathew B (1989). The Genus Lewisia. Portland, OR,USA: Timber Press.

McNeill J, Barrie FR, Buck WR, Demoulin V, Greuter W, Hawksworth DL, Herendeen PS, Knapp S, Marhold K, Prado J, et al., editors (2012). International Code of Nomenclature for Algae, Fungi, and Plants (Melbourne Code) Adopted by the Eighteenth International Botanical Congress Melbourne, Australia, July 2011. Regnum Veg. 154. http://www.iapt-taxon.org/nomen/main.php

McNeill J (1974). Synopsis of a revised classification of the Portulacaceae. Taxon 23: 725728. http://www.jstor.org/stable/1218433

Miller JM, Chambers KL (2006). Systematics of Claytonia (Portulacaceae). Syst Bot Monogr 78: 1-236. https://doi.org/10.2307/25027952

Moreira Muñoz A (2011). Plant Geography of Chile. Berlin: Springer. https://www.researchgate.net/profile/Andres Moreira2/publication/240997817_The Extravagant Physical Geography of Chile/links/0deec534e6f3ba23d6000000/Th e-Extravagant-Physical-Geography-of-Chile.pdf

Muñoz M (1985). Flores del Norte Chico. La Serena (Chile): Dirección de Bibliotecas, Municipalidad de La Serena, La Serena, Chile.

Nagodă E, Comănescu P, Anastasiu P (2013). Phemeranthus confertiflorus: new alien species to Europe. J Plant Develop 20: 141-147.

Nyffeler R, Eggli U (2010). Disintegrating Portulacaceae: a new familial classification of the suborder Portulacineae (Caryophyllales) based on molecular and morphological data. Taxon 59: 227-240.

O’Quinn R[L], Hufford L, Meerow AW (2005). Molecular Systematics of Montieae (Portulacaceae): implications for taxonomy. Biogeogr Ecol Syst Bot 30: 314-331. https://doi.org/10.1600/0363644054223594

O’Quinn RL (2005). Phylogeny, Biogeography and Evolution of Perennation Structures in Montieae (Portulacaceae). PhD dissertation, Washington State University. https://research.wsulibs.wsu.edu/xmlui/bitstream/handle/2376/297/r_oquinn_02090 5.pdf? sequence $=1$

Obbens FJ (2006). A review of the tuberous Calandrinia species (section Tuberosae), including three new species for Western Australia. Nuytsia 16: 9-115. https://florabase.dpaw.wa.gov.au/science/nuytsia/457.pdf

Obbens F[J] (2012). Three new species of Calandrinia (Portulacaceae) from the Eremaean and South West Botanical Provinces of Western Australia. Nuytsia 22: 351-362. https://florabase.dpaw.wa.gov.au/science/nuytsia/640.pdf

Obbens FJ, Hancock LP, Edwards E, Thiele KR (2017). Calandrinia holtumii (Portulacaceae), a new and unusual species from arid Western Australia. Nuytsia 28: 217-223 https://florabase.dpaw.wa.gov.au/science/nuytsia/817.pdf

Ogburn RM, Edwards EJ (2013). Repeated origin of three-dimensional leaf venation releases constraints on the evolution of succulence in plants. Curr Biol 23: 722-726. https://doi.org/10.1016/j.cub.2013.03.029 
Ogburn RM, Edwards EJ (2015). Life history lability underlies rapid climate niche evolution in the angiosperm clade Montiaceae. Mol Phylogenet Evol 92: 181-192. https://doi.org/10.1016/j.ympev.2015.06.006

Otto F, Dietrich A (1833). Cultur y Beischreibung der Calandrinia spectabilis, Nob. einer neuen Zier[p]flanze aus Chili, Familie der Portulaceae. Allgem Gartenzeit 1: 161-2. https://www.biodiversitylibrary.org/item/50795

Pax F, Hoffmann K (1934). Portulacaceae. In: Engler A, Harms H, editors, Die natürlichen Pflanzenfamilien, Ed.2, Vol 16c. Leipzig: Wilhelm Engelmann, pp. 234-262.

Peralta IE (1993). Revalidación de Cistanthe cabrerae (Portulacaceae). Parodiana 8: 271-2.

Peralta IE (1999). Portulacaceae. In: Zuloaga F, Morrone O, editors. Catálogo de las plantas vasculares de la República Argentina, Vol. 2. St. Louis, MO, USA: Missouri Botanical Garden.

Philippi RA (1893a). Plantas nuevas chilenas de las familias rosáceas, onagrariáceas i demás familias del tomo II de Gay: (continuación). Anal Univ Chile 85:299-324. https://doi.org/10.5354/0717-8883.2012.20485

Philippi RA (1893b). Plantas nuevas chilenas de las familias rosáceas, onagrariáceas i demás familias del tomo II de Gay: (continuación). Anal Univ Chile 85: 167-195. https://doi.org/10.5354/0717-8883.2012.20472

Price T. Phylogeny and Evolution of Phemeranthus (Montiaceae) in North American Xeric Habitats. PhD dissertation, Washington University, St Louis. [Electronic theses and dissertations, Paper 724 http://openscholarship.wustl.edu/etd/724].

Reiche K (1897). Zur systematik der chilenischen Arten der Gattung Calandrinia. Ber Deutsch Bot Ges 15: 493-503. https://www.biodiversity.org/page/5001588

Reiche K (1898). Estudios críticos sobre la flora de Chile. Anal Univ Chile 100: 327-371. [Reiche, C (1898). Portulacaceae. In: Reiche C, editor. Flora de Chile, Vol. 2. Santiago: Cervantes, pp. 327-371.] https:/www.biodiversity.org/item/27136

Richardson B (1998-). Calandrinia Kunth. In: Western Australian Herbarium (1998-) FloraBase. Western Australian Flora Department of Biodiversity, Conservation and Attractions Website: https://florabase.dpaw.wa.gov.au/ [accessed 30 March 2018].

Schlechtendal DFL (1831). Litteratur-Bericht zur Linnaea das Jaar 1831. Linnaea 6 Suppl: 1-158. https://www.biodiversitylibrary.org/item/10850

Seddon G (2005). The Old Country: Australian Landscape, Plants and People. Cambridge (UK): Cambridge University.

SEINet (Southwest Environmental Information Network-Arizona chapter) (2018). Website: http://swbiodiversity.org/seinet/index.php [accessed 1 January 2018].

Steudel ET (1840). Nomenclator botanicus, seu, Synonymia plantarum universalis :enumerans ordine alphabetico nomina atque synonyma, tum generica tum specifica, et a Linnaeo et a recentioribus de re botanica scriptoribus plantis phanerogamis imposita. Tubingen: J.G Cottae

https://www.biodiversity.org/item/11567

Syeda ST, Carolin RC (2011). A new species of Calandrinia (Portulacaceae) from Northern Territory, Australia. Proc Linn Soc New South Wales 133: 11-14. https://openjournals.library.sydney.edu.au/index.php/LIN/article/view/5036 
Thiele KR, Obbens F, Hancock L, Edwards E, West JG (2018). (2587) Proposal to conserve the name Parakeelya against Rumicastrum. Taxon 67: 214-215. https://doi.org/10.12705/671.25

Tropicos.org. 2018.Missouri Botanical Garden, St. Louis. Website:

http://www.tropicos.org/Name/26200137 [accessed 25 July 2018].

Veldkamp JF (2015). (2346) Proposal to conserve the name Calandrinia grandiflora

(Cistanthe grandiflora) against Calandrinia glauca (Montiaceae). Taxon 64: 174-

175. https://doi.org/10.12705/636.20

Villagrán C, Marticorena C, Armesto JJ (2007). Flora de las Plantas Vasculares de Zapallar. Santiago (Chile): Puntángeles y Fondo Editorial U.M.C.E.

Wagstaff SJ, Hennion FO (2007). Evolution and biogeography of Lyallia and Hectorella (Portulacaceae), geographically isolated sisters from the Southern Hemisphere. Antarctic Sci 19: 417-426. https://doi.org/10.1017/S0954102007000648

Webster GL (1994). Synopsis of the genera and suprageneric taxa of Euphorbiaceae. Ann Missouri Bot Gard 81: 33-144. http://www.jstor.org/stable/239909

West JG, Chinnock RJ (2013). Calandrinia mirabilis (Portulacaceae), a spectacular new species from Western Australia with notes on its ecology, seed germination and horticultural potential. J Adelaide Bot Gard 26: 97-102. http://www.jstor.org/stable/23874403

Wilson BL, Hipkins VD, Rey-Vizgirdas E, Kaye TN (2005). Variation in Lewisia kelloggii (Portulacaceae) with description of a new species endemic to Idaho. W North Amer Nat 65(3): article 6. http://www.jstor.org/stable/41717467

Zuloaga O, Morrone O, Belgrano MJ (2007). Novedades taxonómicas y nomenclaturales para la flora vascular del cono sur de Sudamérica. Inst Bot Darwiniana 45: 236-241. http://www.scielo.org.ar/pdf/darwin/v45n2/v45n2a11.pdf 